\title{
Land Cover Change of Post-Tin Mining Land Conservation Area and Its Surroundings in Perimping Sub Watershed, Bangka Regency
}

\author{
Meike Erthalia ${ }^{1, *}$, Supriatna ${ }^{1 *}$, and Astrid Damayanti ${ }^{1}$ \\ ${ }^{1}$ Department of Geography, Faculty of Mathematic and Natural Science, Universitas Indonesia, Depok, 16424
}

\begin{abstract}
Tin mining is one of the land uses that causes physical damage to the land. Degraded land due to the mining activity requires a conservation. Conservation of post-tin mining land in Perimping Sub Watershed consists of reclamation and revegetation by planting kinds of fast-growing plants and cover crops. As land management, conservation is conducted to establish the diversity of land cover and to recover the land quality to be more productive for the local people. This study aimed to analyze the land cover change in land conservation of post-tin mining area. Moreover, also to identify the condition of posttin mining land which has been conserved. Land cover map of 2011, 2014, and 2017 were produced from Google Earth imagery. Field validation was conducted to determine the existence of cover types on conservation land and interviews were conducted to find other impact of post-tin mining land conservation for local people. The result shows that land cover change in post-tin mining land conservation area over 6 years dominated by escalation of land cover such as mining, plantations. Monitoring of land cover change in conservation area is important to measure the effectivity of land conservation in post-tin mining area.
\end{abstract}

Keywords: conservation ; land cover ; post-tin mining; Perimping sub-watershed

\section{Introduction}

Tin mining in spatial frame is one of land uses which has particular characteristic [1]. Indonesia tin resources is a representation of the existence of Southeast Asian Tin Belt through the islands of Indonesia [2]. The Indonesian tin belt specifically extends from the northern part of Karimun Island and Bangka Belitung Island is the end of the Indonesian Tin Line [3] [4].

Tin is a natural resource that is explored and made as one of Indonesia's leading export commodities since long time ago. About $90 \%$ of the tin exported by Indonesia is produced from tin mining on Bangka Belitung Island in different mining scales [5]. Tin mining can be found almost in the entire province of Bangka Belitung Islands. Some of it are concentrated in a few areas in between, such as Perimping Sub Watershed.

Tin mining is a temporary land uses activity but has a significant impact on land and environmental quality in the mining and its surrounding areas [7]. Tin mining activities that lasts massively over times can cause an ecosystem damage, which indicated by degradation of soil and water quality, loss of vegetation diversity, and also land conversion [8]. The land conservation is undertaken to improve the quality of degraded land in Bangka Province, particularly in Perimping Subwatershed by reclamation and revegetation of post mining land. Revegetation crops used are fast-grow, cover crop, commodity crops such as rubber, sengon, coconut, fruits, and local plants that are adaptive to the degraded land conditions after mining [9]. Both the reclamation and the revegetation in post mining area would contribute to manage soil organic carbon and its carbon stock. In several studies, reclamation and revegetation can improve significant amount of carbon by reducing the soil erosion and increase the soil organic material that keep carbon stable [20] [21].

The optimum utilization of post-mining land that has been conserved is directed to sustainable land use trend, such as conservation agriculture (CA), and expected to help the local community's economy. Furthermore, the sustainable land cover and land use conservation area would also help the community to become low-carbon society [23].

Post-tin mining conservation activities in Bangka Regency are big challenge for mining business actors. Especially when small scale miners become more massive since 2001. Oftenly, as consequence the conservation faced its grief before it can be utilized by the government and surrounding communities. Therefore, monitoring of land conservation is required.

Land conversion during the mining process until the conservation and utilization stage of sustainable postmining land use can be observed by mapping the changes in land cover in mining and its surrounding areas [12] [13]. This study applied remote sensing images of post tin mining in temporal scales and also

Corresponding author: ysupris@yahoo.com. 
field survey to identify the land cover changes in the post-tin mining conservation area. Mapping for land cover changes can provide preliminary information on monitoring and assessing the conservation land. The Post-mining conservation land is successful if it no longer occupied as mining area. Furthermore, there is a succession from the revegetation, and found activities in post-mining land that leads to the agricultural sector [14].

\section{Materials and Method}

This study was conducted in Perimping Sub Watershed is part of the Layang Watershed which is one of the large watershed in Bangka Regency. About 23. 24\% of Bangka Regency regional income is come from mining sector [6]. So that mining activities become an important sector in the regional economy. The area of Perimping Sub Watershed is covering covering 3 subdistricts in Bangka, which are Riau Silip Sub District, Bakam Sub District, Pemali Sub District. The topographical condition dominated by slope around $0 \%$ $-15 \%$. It is also dominated by the height between $0-25$ above the sea level. Miners, farmers, and grocery businesses are the most common livelihood of people who lived in Perimping Sub Watershed area.

\subsection{Materials and Methods}

Identification of land cover changes in post-mining land conservation areas was by interpreting several types of multispectral imagery in 2011, 2014, and 2017 downloaded from the google earth app. The google earth app can display a variety of high-resolution imagery according to the desired time scale. The image criteria that used for this research were (1) Digital Globe Image on September 5, 2011, (2) Air Bus Imagery dated September 1, 2014 and July 22, 2017. Images from various satellites which displayed in the google earth app have been corrected so they are ready for processing [15]. Images downloaded using SMARTGIS software and processed by doing digitization (delineation of land cover area) using software ArcGIS 10.1. The land cover map would be displayed with land cover classification with codes: $1=$ Conservation Land; $2-=$ Kolong or or Pit ; $3=$ Bare Land ; $4=$ Plantation and $5=$ Bush. Field validation was also conducted to determine the existence of cover types and interviews were conducted to find other impact of posttin mining land conservation for local people.

\section{Result and Discussion}

Mining industry in the Perimping Sub-basin area consist of 3 types of miners. (1) Large-scale miners consisting of several mining companies such as PT. Timah Tbk, PT. Refined Bangka Tin, dan PT Babel Timah Sejahtera. (2) Miners known as TN (Non-Conventional Mines) are also partners of large tin companies such as PT Timah. (3) Unconventional Miners (TI) who are small-scale miners. TI mostly use small mechine that has small capacity such as Domfeng 7 PK for spraying and hoe for excavation.

\subsection{Post-Tin Mining Land Characteristic}

Tin mining in the research area is generally occupied as an open pit mining. The open pit mining process consists of stripping top soil, excavation, and spraying steps to separate the tin deposits, sand and soil mixtures that contained each digged soil [16]. The mining process with the top soil removal and excavation is what caused the critical land. So, the critical land of post-tin mining area has different characteristics with its surroundings and can be easily observed through an imagery.

Treatment of degraded land caused by tin mining as in Fig 2 is the obligation and resposibility of the miners (ESDM ministerial regulation No. 18 Tahun 2008 About Reclamation and Mine Closure) [17]. After that, the conservation land or the rehabilitated land is should be returned to the local government. The goal is that land that has been reclaimed, replanted (revegetation), and orgenized would become productive land such as for agriculture, fisheries, and even as tourism sector facilities.

Post-tin mining land that has not been conserved generally consists of a dry pile of tailings and basins commonly named as kolong [18] [12]. Post mining land in the Perimping Sub Watershed that has not been conserved were characterized as sandy tailing slime and a mixture of both. In addition, there were also underdated with the size of a small diameter to more than 100 $\mathrm{m}$. Post-tin mining land in the Perimping Sub watershed can be found among the settlements, between plantation areas, and along local roads that have been passed during the field survey.

Post-mining land that has not been conserved in the research area is mostly located in the Mining Business License area (IUP) owned by PT. Timah, Tbk. IUP of PT Timah in the location of research is not only concessioned by PT Timah, Tbk itself, but also by other miners who are partners of PT Timah, Tbk. Although they recognized and status as business partner, but the miners also have an obligation in the term of postmining land management and conservation.

\subsection{The Procedures of Post-Tin Mining Land Conservation}

Post mining conservation in Perimping Sub-basin is done through several stages. The conservation stage is adjusted to the post-mining land characteristic but still includes the reclamation and revegetation phase. The information obtained from the interview with Supervisor of Reclamation from K3LH division of PT Timah, Tbk about the post-mining land conservation stage commonly used by large-scale miners.

The conservation phase begins with planning. Planning includes mapping and identification of post-tin mining area, observation of damage levels, determination of work partners which could provide the reclamation process, and costs of the conservation program. Next is the post-mining landscaping stage. 
The landscape arrangement begins by flatten the mound of tailings and overburden and under-stocking the pit using tailings. The purpose is that mine land with irregular topography can be more even and can be planted with the crops. The stage is continued by making drainage to control the erosion and to prevent damage to land reclamation.

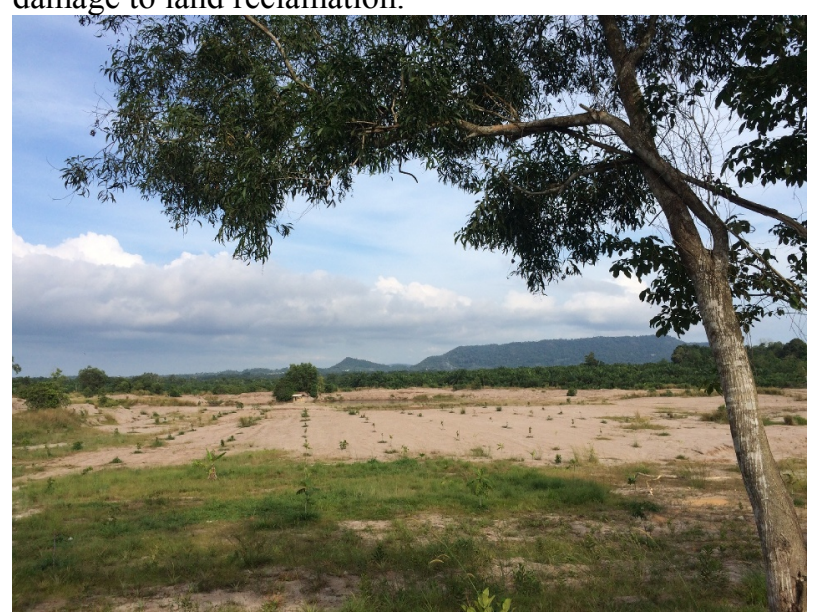

Fig 1. Revegetation Pattern at Post Tin Mining Area in Pemali, Bangka Regency

Then after flatten process, the land is prepared for revegetation with several types of crops. Referring to the ESDM Ministerial Regulation No. 7 Tahun 2014 Implementation of Reclamation and Post Mining in Mining Activities, the type of revegetation crop such as fast-growing, overcrop, and local crops should be included.

Every $1 \mathrm{Ha}$ of post mining land, PT Timah, Tbk revegetated the land by planting approximately 625 trees with $4 \mathrm{~m}$ distance between each tree (Fig 1). The proportion of the planting is 468 in the form of a (Paraserianthes falcataria), tree which can grow very quickly [19]. This is because, basically post-mining land is conserved to return as peruntukkannya in short period. The remaining 25\% were planted with overcrop and selected local crops, such as cashew (Anacardium occidentale).

Plants will be put into special pots such as polybag with mixture of topsoil, dolomite, compost, and MPK as the initial planting medium before it can adapt to tailings land. Maintenance such as fertilizer, cleaning, planting will be done 8 times in term of 2.5 years. In addition, pest plant sparying with certain pesticide fluid also required as much as 1 time a year.

After 2.5 years of maintenance and monitoring, the post-mining tin conservation land will be assessed by ESDM Ministery and then will be returned its land rights to the local government. The government reserves the right to transfer the function of the post-mining tin conservation land for the benefit of the people and the regional income such as settlements, plantations, and so on except for mining consession. This is because after conservation land is assessed by ESDM Ministery then it is no longer allowed to be mined. It is at this stage that conservation results are often found to be damaged due to lack of monitoring and maintenance of conservation land. Point 3.3 will describe one of the conservation sites as an illustration of how the postmining tin conservation area is present in the Perimping Sub Watershed region over a period of times.

\subsection{Spatial Pattern of Land Cover Change in Conservation and Surroundings Area (2011 2014, and 2017)}

One of the conservation sites in the Perimping Subwatershed is Reklamasi Pelempang. Located in Bukit Layang Village, Bangka Regency (Fig.2). Post mining conservation at this location was done by PT Timah, Tbk in between 2007-2010. Conservation was about the reclamation of severals pit and revegetation with the type of timber plants.

The land conservation in this site were carried out periodically on some parts of unoccupied mining land. Post tin mining land conservation conducted in Perimping Sub Watershed was reconducted in 20062007. Conservation once discontinued in 2001 when widespread and massive illegal miner were ruined the land reclamation and revegetation there. After 6 years conservation of post- tin mining land has begun to show results. Over past 6 years after the conservation, the condition of the land conservation in Reklamasi Pelempang site and surrounding area shows the change and distribution of its land cover.

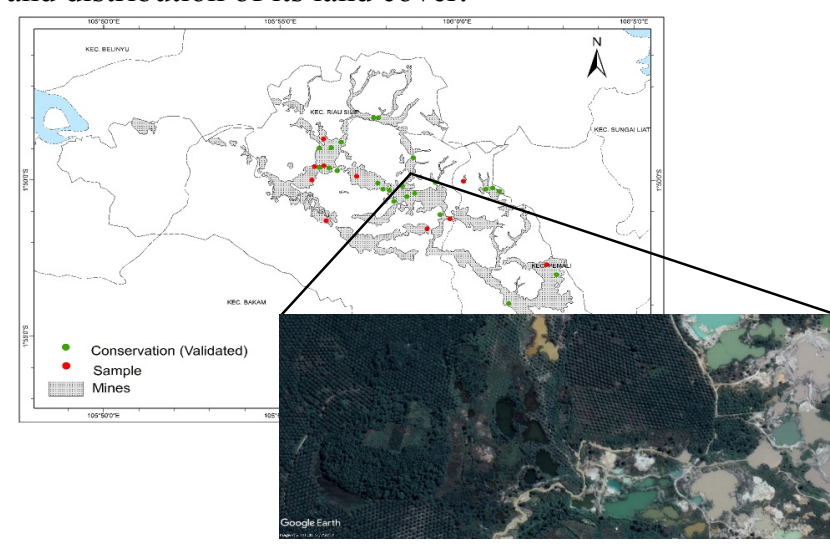

Fig 2. Site of Reklamasi Pelempang, Desa Bukit

Tabel 1. Magnitude of Land Cover Change in Conservation and Surroundings Area 2011 2014, and 2017 (in $\mathrm{Km}^{2} / \%$ )

\begin{tabular}{|c|c|c|c|c|c|}
\hline No & $\begin{array}{l}\text { Land Cover } \\
\text { Classification }\end{array}$ & 2011 & 2014 & 2017 & Details \\
\hline 1 & $\begin{array}{l}\text { Conservation } \\
\text { Land }\end{array}$ & $\begin{array}{r}0.267 / \\
38.8\end{array}$ & $\begin{array}{r}0.272 / \\
39.6\end{array}$ & $\begin{array}{r}0.230 / \\
33.5\end{array}$ & Loss \\
\hline 2 & Kolong / Pit & $\begin{array}{r}0.052 / \\
7.6 \\
\end{array}$ & $\begin{array}{r}0.073 / \\
10.7\end{array}$ & $\begin{array}{r}0.082 / \\
11.9 \\
\end{array}$ & Gain \\
\hline 3 & Bare Land & $\begin{array}{r}0.019 / \\
2.8 \\
\end{array}$ & $\begin{array}{r}0.032 / \\
4.7 \\
\end{array}$ & $\begin{array}{r}0.034 / \\
5.0 \\
\end{array}$ & Gain \\
\hline 4 & Plantation & $\begin{array}{r}0.270 / \\
39.3 \\
\end{array}$ & $\begin{array}{r}0.280 / \\
40.8 \\
\end{array}$ & $\begin{array}{r}0.309 / \\
45.0 \\
\end{array}$ & Gain \\
\hline 5 & Bush & $\begin{array}{r}0.079 / \\
11.4\end{array}$ & $\begin{array}{r}0.029 / \\
4.2\end{array}$ & $\begin{array}{r}0.032 / \\
4.6\end{array}$ & Gain \\
\hline & Total & $\begin{array}{r}0.687 / \\
100 \\
\end{array}$ & $\begin{array}{r}0.687 / \\
100 \\
\end{array}$ & $\begin{array}{r}0.687 / \\
100 \\
\end{array}$ & \\
\hline
\end{tabular}

Overall, the land cover change of this site shows that conservation is the only land cover that loss. The distribution of land cover for plantation land were 
entered and overlapping the post tin mining conservation area which conducted by PT Timah, Tbk. The map of land cover change in the Pelempang conservation area and its surrounding can be observed in (Fig. 2). The pattern of land cover change is significant in the north and part of the center. A description of the change in the area of each land cover can be observed in Table 1.

\subsection{Magnitude and Spatial Pattern of Land Cover Change in Conservation and Surroundings Area (2011 and 2014)}

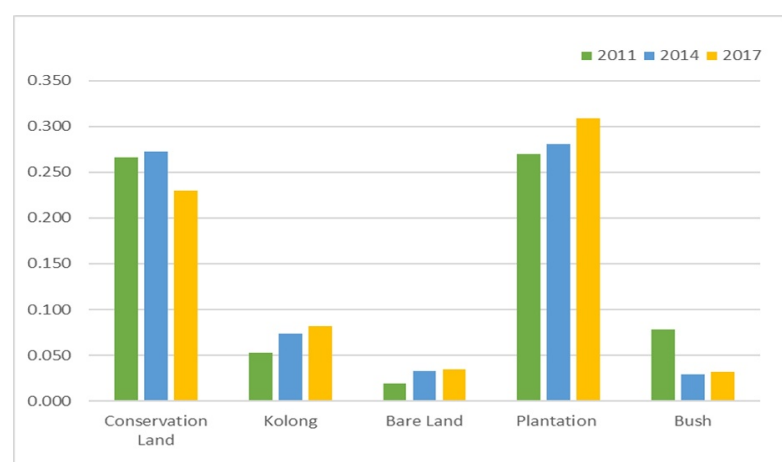

Fig. 3. Graphic of Land Cover Change in 2011 and 2014

The conservation area at this location in 2011 was 0.267 $\mathrm{Km}^{2}$, which also as land cover that dominated the most. (Fig 3). Plantation was also dominated about $0.270 \mathrm{~km} 2$ or covering 39.319\% the site of Reklamasi Pelempang and surrounding areas. Based on imagery interpretation, the land cover change was clearly appeared in 2014. There were increased of kolong or pit which concentrated in the eastern and central part. As observed Fig 4, kolong or pit were found in the middle of the conservation area. This was indicated that after more than 3 years since conservation has done, there were remining in certain parts of the conservation area. Eventhough, From Fig 4 and Table 1 shows that all land covers were gain more wider, unless the bush which decreas from $0.079 \mathrm{Km}^{2}$ in 2011 to $0.029 \mathrm{Km}^{2}$.

\subsection{Magnitude and Spatial Pattern of Land Cover Change in Conservation and Surrounding Area (2014 and 2017)}

In 2017 a reduction in the post mining land is also followed by an increase of area of kolong or pit. However, a significant change in land cover converting former mining land was conservation of plantation land. The area of plantation in 2014 was $0.280 \mathrm{Km}^{2}$, then in the past 3 years, the area increased to $0.309 \mathrm{Km}^{2}$ in 2017. This indicated that post-mining land use efforts have been conserved in the form of revegetation by other parties.

Revegetation of the post- tin mining conservation land was done by palm oil plantations company. The oil palm plantation company was used the post-tin mining conservation land as a medium for its plantation. The process of oil palm planting in ex-mining areas was also through the reclamation procedures of pit in certain depth. Overall, however, conservation land based on the land cover change in two periods were indicated that there were still mining process within the conservation area, which means the conservation still not effective yet. Later, the land cover change and land use conversion would be matter considering land use and land cover change have a significant effect to the global carbon cycle [22].
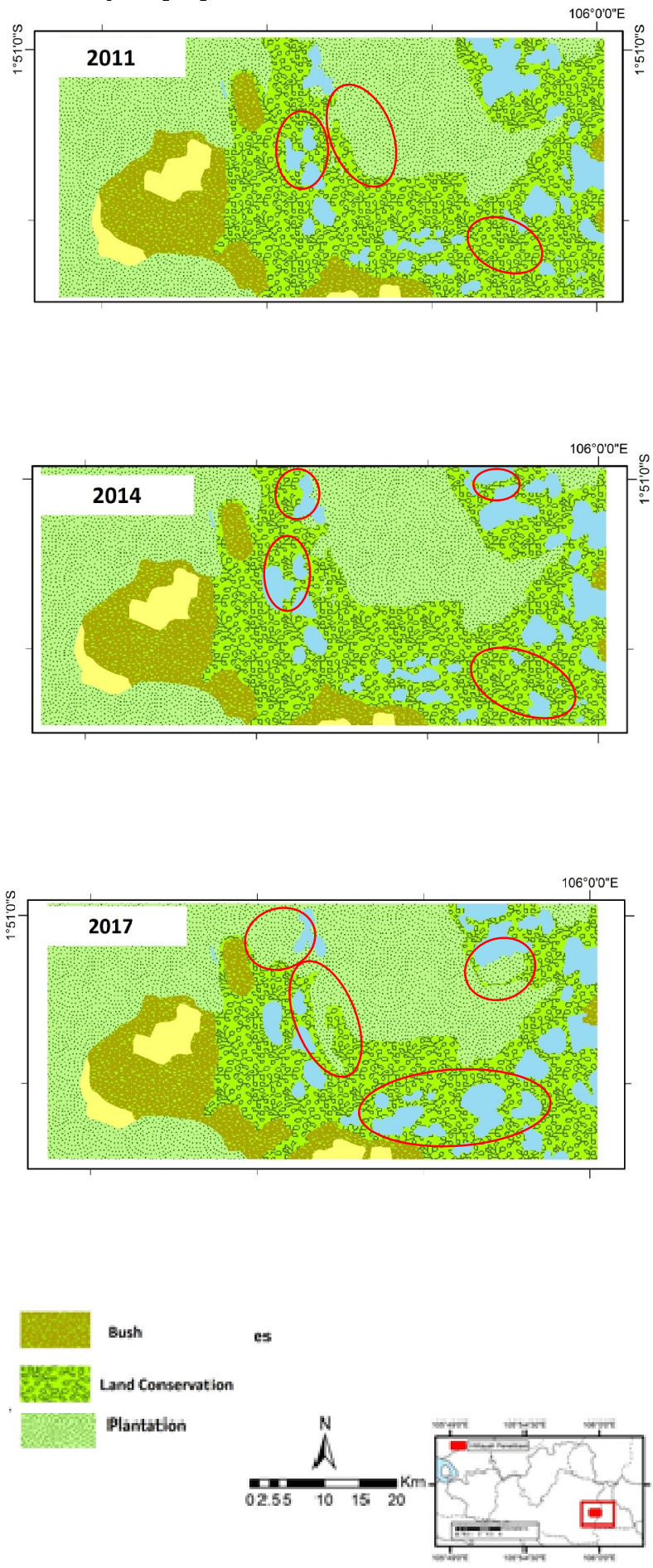

Fig 4. Map of Land Cover Change in Conservation and Surroundings Area

The fact showed from field and interview with 30 of local people around the conservation area, almost $80 \%$ of them answered that post-mining land conservation has not provided any beneficial impact to the local 
people. Therefore, people choose to cultivate their own former mining land around their house with plants such as rubber, dragon fruit, cashew, guava, coconut, chili and sahang (pepper). The plants in addition to adaptive to the former mining area also have economic value. On the other hand, the community still chooses to mine at the conserved site though with little profit. But, the conserved land has also been utilized as a medium for planting agricultural crops and plantation commodities that have value for sell. That was actually showed that conservation land of post tin mining can provide economic benefits to the surrounding community, but proper management and land use system were absolutely needed.

In monitoring and managing the results of post-tin mining land conservation genuinely need well coordination from various parties. The government and society have a big part in supporting more sustainable and environmentally friendly mining program. In addition, community awareness is needed in the maintenance and reuse of post mining land for more productive activities. The benefits will be felt by the community itself. Information of progress of post-tin mining land conservation results is also important to be collected considering to be used for regional spatial consideration and one also as one of the watershed management efforts [10]. Controlling the conservation area in Sub DAS Perimping is important, in order that Layang watershed as its main watershed is still classified in Priority II basin.

\section{Conclusion}

The result shows that land cover change in post-tin mining land conservation area of Pelempang over the 6 years dominated by escalation of land cover such as mining, plantations. In general, land cover change in land conservation areas and surrounding may indicate that conservation is under way yet to work properly, as mining is still found within conservation areas. Thus, it can be preliminary monitoring proceses, which the monitoring of land cover change in conservation area is important due to measure the effectiveness of land conservation that have been done, also as consideration to achieve the low carbon society in mining community. Utilization of remote sensing data can assist the parties involved in conservation activities to keep monitoring the conservation results that have been done from a distance.

\section{Acknowledgment}

Thanks are due to DPRM Universitas Indonesia which has supported and funded this research in HIBAH PITTA UI 2018, PT Timah, Tbk and Bukit Layang Village Communities who have been assisted this research and the availability of research data.

\section{Reference}

1. I.M. Sandy. Penggunaan Tanah (Land-Use). (1995).
2. A.J. Barber, M.J.Crow, J.S. Milson. Sumatera: Geology, Resouces, and Tectonic Evolution. London: The Geological Society (2005).

3. E.J. Cobbing, P.E.J. Pitfield, D.P.F. Darbyshir, and D.LJ. Mallick. The Granites of The South-East Asian Tin belt. Overseas Memoir 10, British Geological Survey. (1992)

4. S.Wai-Pan, J. W. Martin, M. H. Roselee., C. Teschner. et al. Journal of Asian Earth Science, 138, 548-561 (2017)

5. IDH. IDH Tin Working Group Communiqué (2013)

6. Badan Pusat Statistik Kabupaten Bangka (BPS). 2016. Kabupaten Bangka dalam Angka Tahun 2016.

7. T. Lestari, Z. Abdi, J. Wibowo, Yohanes. Eviagro, Jurnal Pertanian 2, 1-5 (2008)

8. S. Kivien. Sustainable Post-Mining Land Use: Are Closed Metal Mines Abandoned or Re-Used Space. Journal of Sustainability, 9 Hal. 3-18 (2017)

9. E. Nurtjahya, and F, Agusna. Managing the socioeconomic impact of tin mining on Bangka Island, Indonesia - preparation for closure. Mine Closure (2015).

10. A. Damayanti. Kebijakan Pembangunan Wilayah Berbasis Pengelolaan DAS Terpadu dan Bekelanjutan (2010)

11. I. Inou. Pengelolaan Lahan Tiling Timah di Pulau Bangka: Penelitian yang Telah Dilakukan dan Prospek Kedepan. Bangka Belitung: Program Studi Agroteknologi, Universitas Bangka Belitung (2007)

12. S.J. Ndace, Danladi, Musa H. Journal of Sustainable Development, 5 (2012)

13. H. Herold 2017. High Resolution Land Cover Mapping. Amerika: National Coastal Management (NOAA).

14. A. Kodir, M. D. Hartono, H. Haeruman, I. Mansur. Sustainable Environment Research, 27, 203-2013 (2017)

15. N. Hayati, and M. Taufik Kajian Penelitian Planimetris Citra Resolusi Tinggi Pada Google Earth untuk Pembuatan Peta Dasar Skala 1:10000 Kec. Banjar Timur Kota Banjarmasin (2005)

16. S.R.P. Sitorus, E. Kusumastuti, L.N. Badri. Jurnal Tanah dan Iklim 27, 57-74 (2008)

17. Permen ESDM No. 18 Tahun 2008 (Tentang Reklamasi dan Penutupan Tambang)

18. S. Sujitno. Sejarah Penambangan Timah di Indonesia Abad ke 18-Abad ke 20. PT Timah: Pangkalpinang (2007)

19. D. Setiadi, L. Baskorowati, Susanto, and Mudji. Jurnal pemulihan tanaman Hutan, 8, 121-136 (2014)

20. T.A. Gessesse, G. Halldorsson, A.M. Agustsdottir, B. Slater. Assesment of The Impact of Different Revegetation Methods on Soil Carbon Stock in Iceland. Land Restoration Training Progamme (2009) 
21. Y. Li, J. Jiao, Z. Wang, B. Cao, Y. Wei, S. Hu. Int J Environ Res Public Health, 13 (2016).

22. L. Deng, G.B. Liu, Z. P. Shangguan. Global Change Biology, 20 (2014).
23. C.D. Campbell, A. Lilly, W. Towers, S.J. Champan, A. Werrity, N. Hanley. Land Use and Low-Carbon Society. Earth and Environmental Science Transaction of The Royal Society of Edinburgh, 103 (2012). 